\title{
Archaeological Investigations at the Henry M. Site (41NA60): An Early Historic Caddo Farmstead in Nacogdoches County, Texas
}

Tom Middlebrook

Heritage Research Center, Stephen F. Austin State University

Timothy K. Perttula

Heritage Research Center, Stephen F. Austin State University

Follow this and additional works at: https://scholarworks.sfasu.edu/ita

Part of the American Material Culture Commons, Archaeological Anthropology Commons, Environmental Studies Commons, Other American Studies Commons, Other Arts and Humanities Commons, Other History of Art, Architecture, and Archaeology Commons, and the United States History Commons

Tell us how this article helped you.

This Article is brought to you for free and open access by the Center for Regional Heritage Research at SFA ScholarWorks. It has been accepted for inclusion in Index of Texas Archaeology: Open Access Gray Literature from the Lone Star State by an authorized editor of SFA ScholarWorks. For more information, please contact cdsscholarworks@sfasu.edu. 
Archaeological Investigations at the Henry M. Site (41NA60): An Early Historic Caddo Farmstead in Nacogdoches County, Texas

\section{Creative Commons License}

\section{(c) (1) (8)}

This work is licensed under a Creative Commons Attribution-NonCommercial 4.0 International License 


\title{
Archaeological Investigations at the Henry M. Site (41NA60): An Early Historic Caddo Farmstead in Nacogdoches County, Texas
}

\author{
Tom Middlebrook and Timothy K. Perttula
}

\section{INTRODUCTION}

The Henry M. site (41NA60) is an early historic (post-A.D. 1680) Allen phase farmstead on a natural rise in the Bayou Loco lloodplain in western Nacogdoches County in East Texas. Bayou Loco, a relatively small stream, flows south a few miles to its confluence with the Angelina River. The dam for Lake Nacogdoches on the bayou is about 1.7 miles to the north. Construction of Lake Nacogdoches inundated a number of contemporaneous Allen phase farmsteads-some of which were the scene of 1970 s excavations-including 41NA18, Mayhew
(41NA21), Iron Rock (41NA22), Loco Botloms (41NA23), and Deshazo (41NA27) (see Kenmotsu 1992; Middlebrook 2007; Story 1982, 1995). The Bayou Loco valley has a high density of historic Caddo settlements (Middlebrook 2007:107-108).

The natural rise that the Henry M. site is located on was in an 8 acre pasture (Figure 1). This rise is about $50 \mathrm{~m}$ in diameter, ca. $1 \mathrm{~m}$ in height, and south a short distance from an eastward-flowing spring-fcd tributary to Bayou Loco. The rise has loamy alluvial Marictta soils.

The main part of the Henry M. site has a ca. 10 $\mathrm{m}$ diameter midden deposit near the center of the

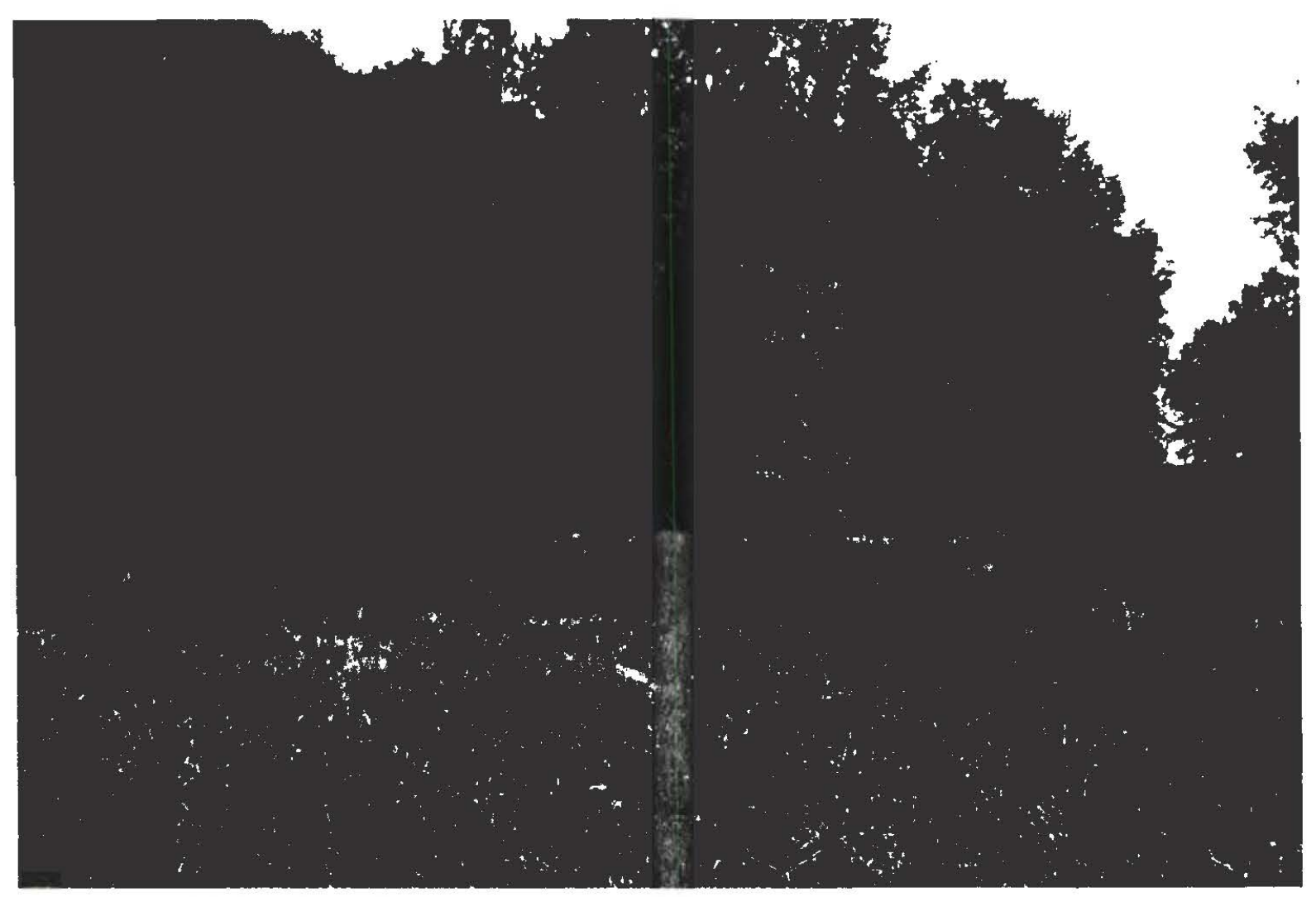

Figure 1. The Henry M. site in the mid-1980s. 


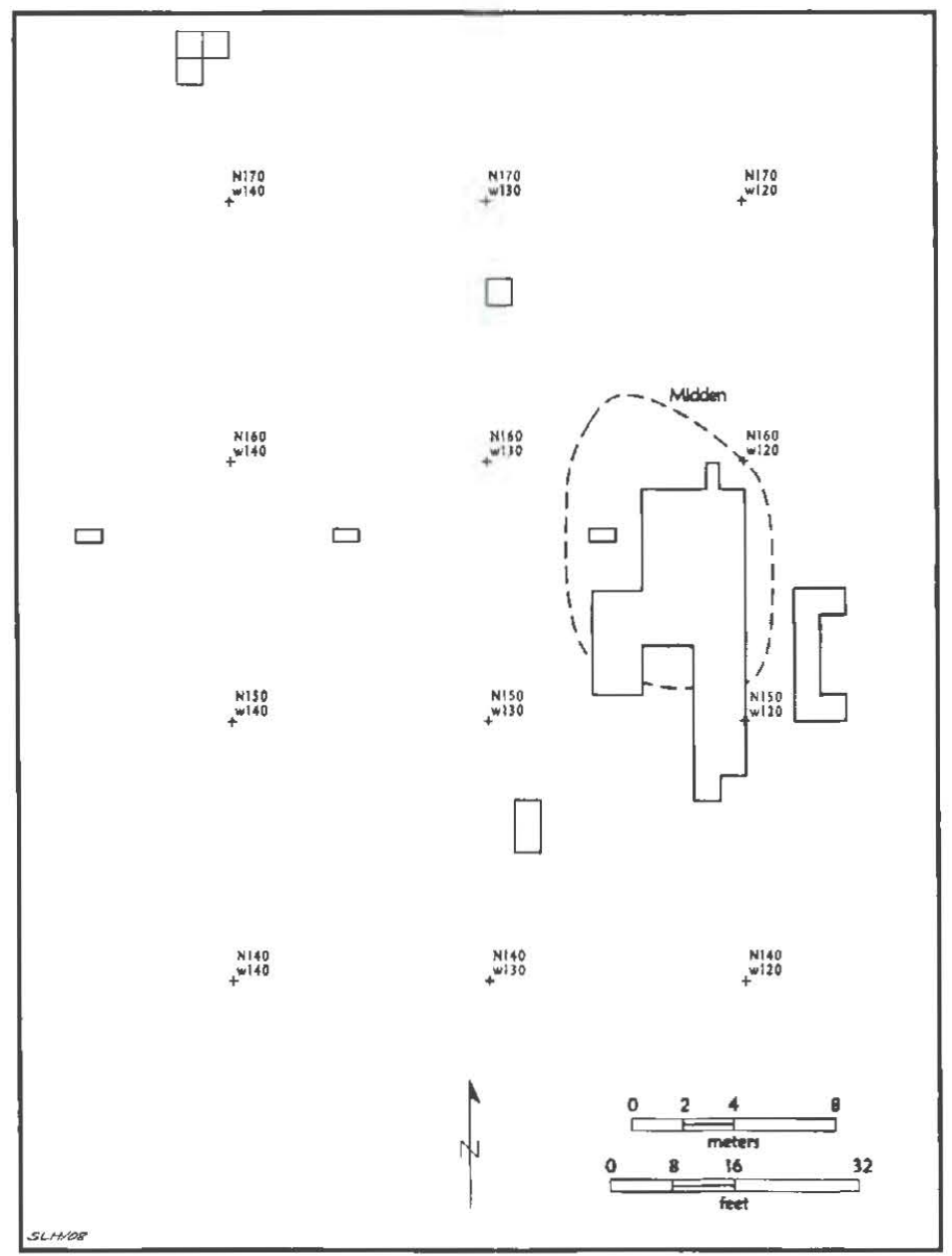

Figure 2. Excavations and midden area at the Henry M. site (4INA60).

natural rise (Figure 2). The midden deposit contains extensive amounts of Caddo ceramic sherds and many well-preserved animal bones, some mussel shell, and other artifactual dcbris.

\section{ARCHAEOLOGICAL INVESTIGATIONS}

Tom and Janice Mayhew recorded the Henry M. site in 1973, and collected a few Caddo sherds-among them Patton Engraved sherds, the principal engraved fine ware type found in Allen phase sites-and some animal bones. In 1985, Tom Middlcbrook began excavations at the site, focusing on the well-preserved midden deposits (see Figure 1). Excavations continued sporadically through 1991 under Middlebrook's supervision, and a total of $55 \mathrm{~m}^{2}$ (including $50.25 \mathrm{~m}^{2}$ in a large block of virtually contiguous $1 \times 1 \mathrm{~m}$ units) and $22 \mathrm{~m}^{3}$ of archaeological deposits were examined during this work (Middlebrook 2007:111).

Archaeological sediments in the midden excavations at Henry $M$. include four zones, from top to bottom:

(1) a dark brown sandy loam plow zone about $10-15 \mathrm{~cm}$ thick; (2) a very dark grayish-brown sandy loam midden (Figure 3) with a greasy fecl, being flecked with charcoal and bone, as well as many large ceramic sherds; this midden deposit is about $10 \mathrm{~cm}$ in thickness; (3) a submidden, but anthropogenic, zone 10-15 $\mathrm{cm}$ thick of brown to dark brown sediments, apparently stained and/or mixed with the overlying midden; this zone may represent the original A-horizon ground surface at the time of the early Historic Caddo occupation; and (4) a dark yellowish-brown sandy clay B-horizon. 


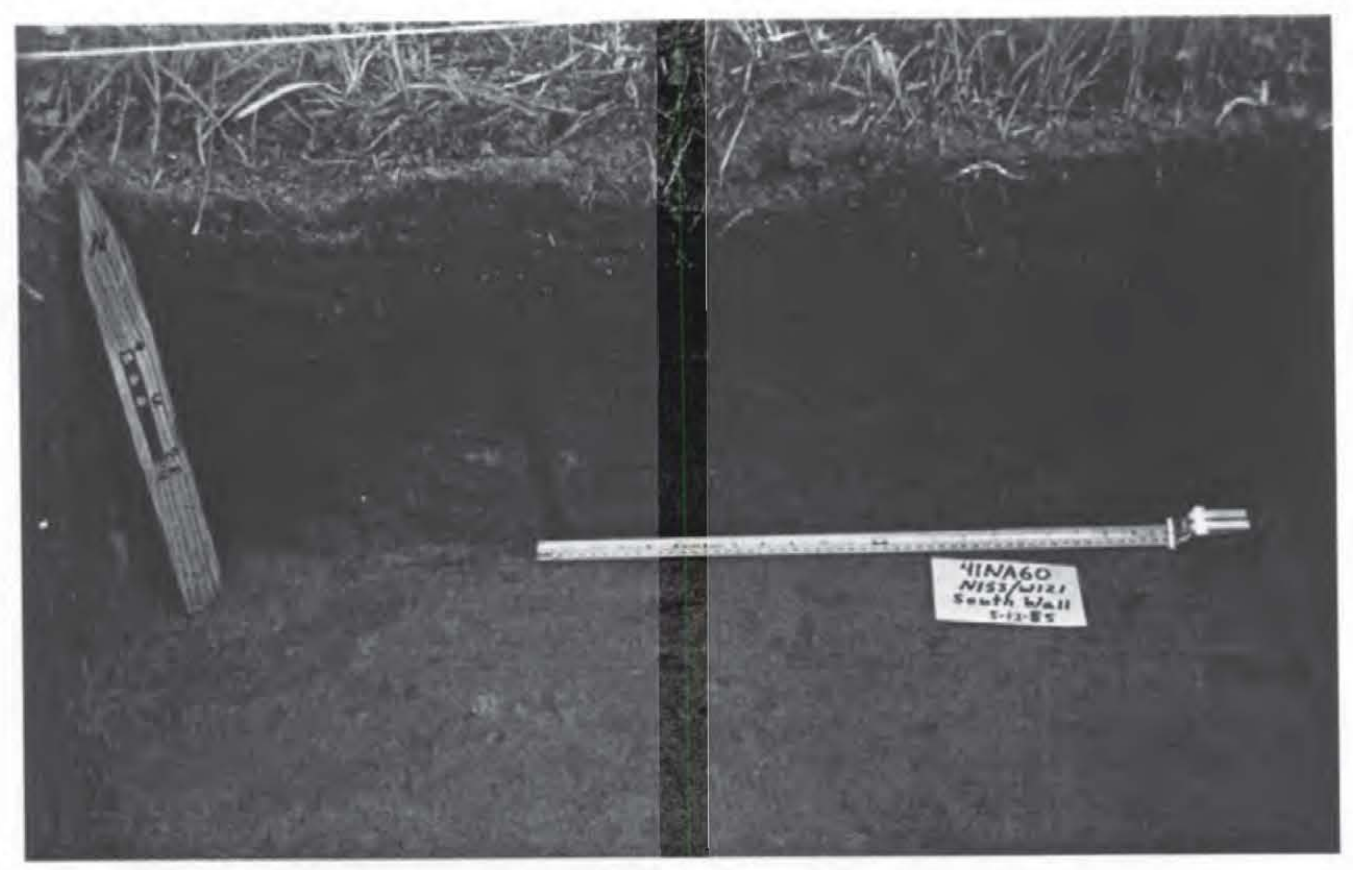

Figure 3. Profile of N153 W121, south wall.

Cultural features and anomalous staining evident in the excavations strikingly contrast with the B-horizon dark yellowishbrown color.

\section{BLOCK EXCAVATIONS AND CULTURAL FEATURES}

During the block excavations a large number of cultural features and likely cultural features/ stains were identified and documented as to their size, shape, and midden-stained fill (Figure 4). The majority of these are post hole-sized (e.g., $15-20 \mathrm{~cm}$ in diameter) features that are part of a large circular structure, two central post features (Features 1 and 2) (Figure 5a-b), and various external and internal post hole stains (Figure 6). The Caddo structure, although not completely defined, appears to have been $\mathrm{ca} .8 .8 \mathrm{~m}$ in diameter, slightly smaller than the 9.0-12.2 m diameter circular structures at the Deshazo site (Good 1982:53). At the Deshazo site, the structures had their entrances opening to the north $(n=1)$, northeast $(n=2)$, northwest $(n=1)$, south $(n=4)$, southeast $(n=1)$, and southwest $(n=2)$. More excavations in the block at the Henry M. site are needed to clarify the interior (i.e., including how many support posts were used in house construction, if any) and exterior character of the post hole pattern of this circular structure, but there is an obvious gap in post holes along the western wall arc that suggests the structure entrance was in this part of the structure (see Figure 4).

The fact that there are two central posts, and that several post hole features (Features 5, 6, and 8) along the exterior wall overlap or intersect (Figure 7; see also Figure 4), indicate that the structure at the Henry M. site was at least partially rebuilt on one occasion. Feature 1 apparently is the initial center post, set in an irregular $50-60 \mathrm{~cm}$ diameter hole. The second and possibly later center post (Feature 2) is about $40 \mathrm{~cm}$ in diameter, filled with ash, midden sediments, a rock, a burned deer antler, and a large conch shell (Busycon sp.) scoop (Figure 8; see also Middlebrook and Middlebrook 1996: Figure 3).

There are also two post hole-sized ash features about $2-2.5 \mathrm{~m}$ distance from the central posts. These may be the remains of totally combusted post features, or distinctive small cooking pit features. A few of the possible cultural features/stains in the excavations are larger than post holes, and are likely small pits used for different purposes, including cooking, heating, ctc.

Immediately to the north of the postulated exterior structure post hole arc is a ca. $1.8 \times 1.6 \mathrm{~m}$ area of post holes and one pit feature (Feature 18, see Figure 4) that may represent the posts to an outdoor storage platform/granary or above-ground arbor. Good (1982:61) noted that such storage platforms were commonly located in front of historic Caddo 
structures, and thus it is possible that the structure entrance was actually near this outdoor facility.

\section{RECOVERED ARCHAEOLOGICAL MATERIALS}

Much of the archacological materials from the Henry M. site remain to be analyzed in detail, and that work is in progress. Middlebrook (2007:111) tabulated an $18 \%$ sample of artifact lots from the excavations, and they contained 398 ceramic sherds, 10 arrow points, and almost 3000 animal bones (Table 1). Among the sherds were 16 Patton Engraved pieces, 31 other engraved sherds, 265 brushed sherds, one neck banded sherd, 31 incised or punctated pieees, and 54 plain body and base sherds.

There is a single large clear olive-shaped glass bead from deposits inside the structure. This appears to be a Ila15 drawn bead (Kidd and Kidd
1970:Table 2). This kind of bead has been found in ca. A.D. 1680 to ca. 1740 contexts in East Texas and Northwest Louisiana Caddo and colonial era sites (Avery 2005:Figure 4 and Table 3; Perttula et al. 2005:93-94).

\section{SUMMARY AND FUTURE PLANS}

Excavations between 1985-1991 at the Henry M. site on Bayou Loco have exposed a well-preserved midden deposit that partially overlaps a ca. $8.8 \mathrm{~m}$ circular Caddo structure (apparently rebuilt to some extent) marked by a variety of cultural features and stains, including two central posts from sequent structure use. There is a probable storage platform or arbor just outside the north wall of the structure.

Recovered archaeological materials are representative of Allen phase domestic activities, including food processing, cooking, and serving foods,

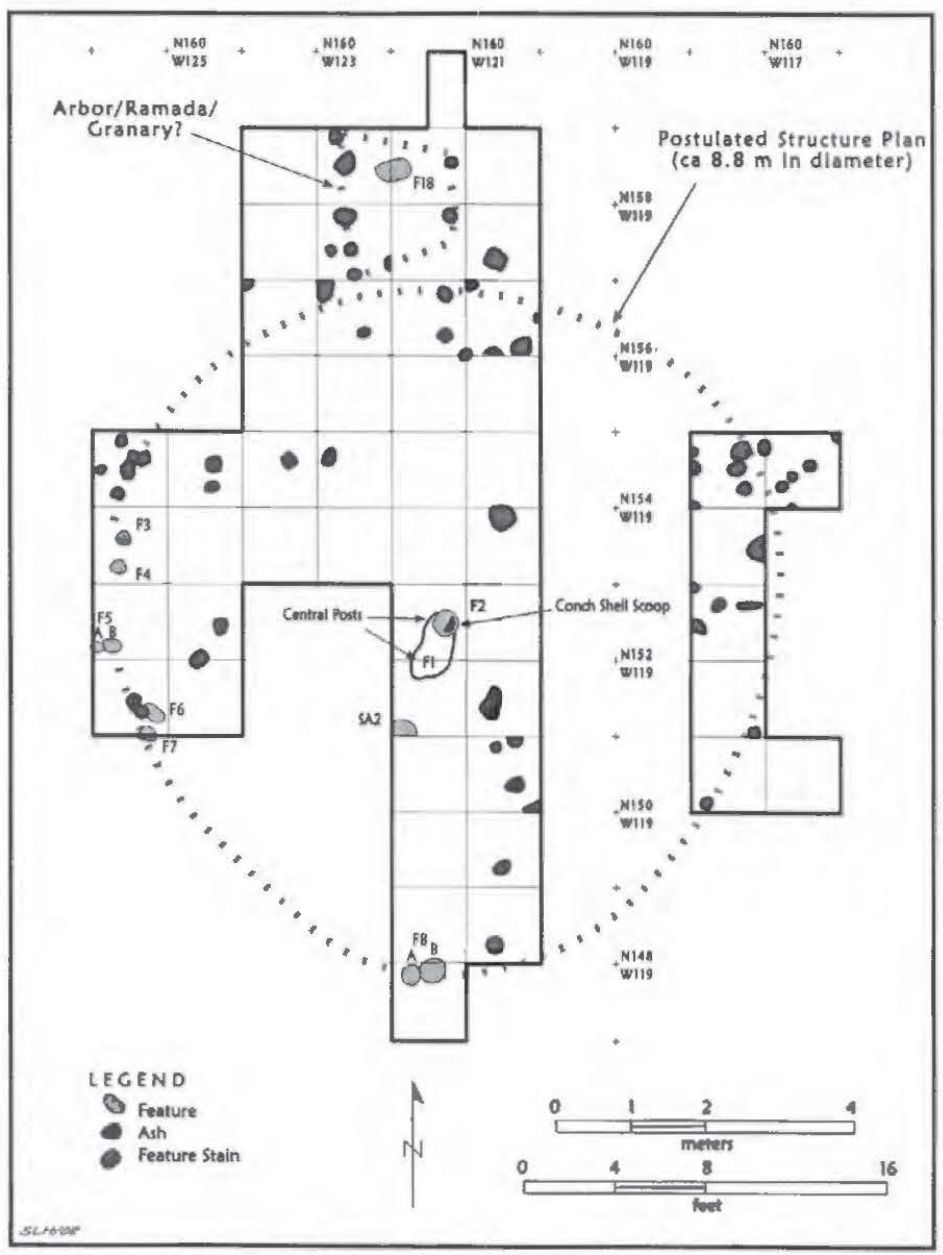

Figure 4. Cultural features and likely feature stains in the block excavations at the Henry M. site. 

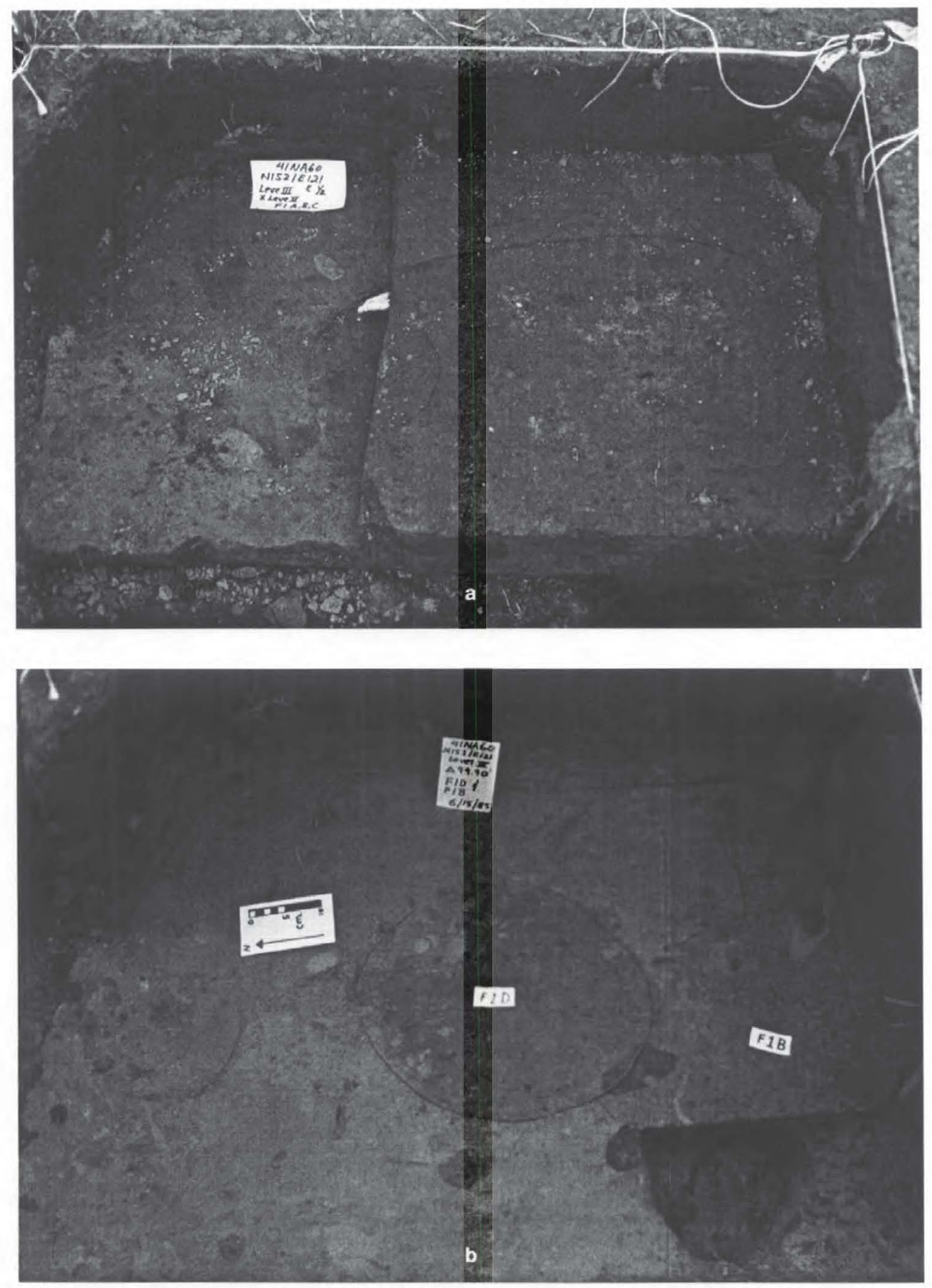

Figure 5, Feature 1 center post exposure and Feature 1 sub-features: a, exposure of Feature 1 in N152 W121; b, Feature $1 \mathrm{~B}$ and $1 \mathrm{D}$ in N152 W121. 


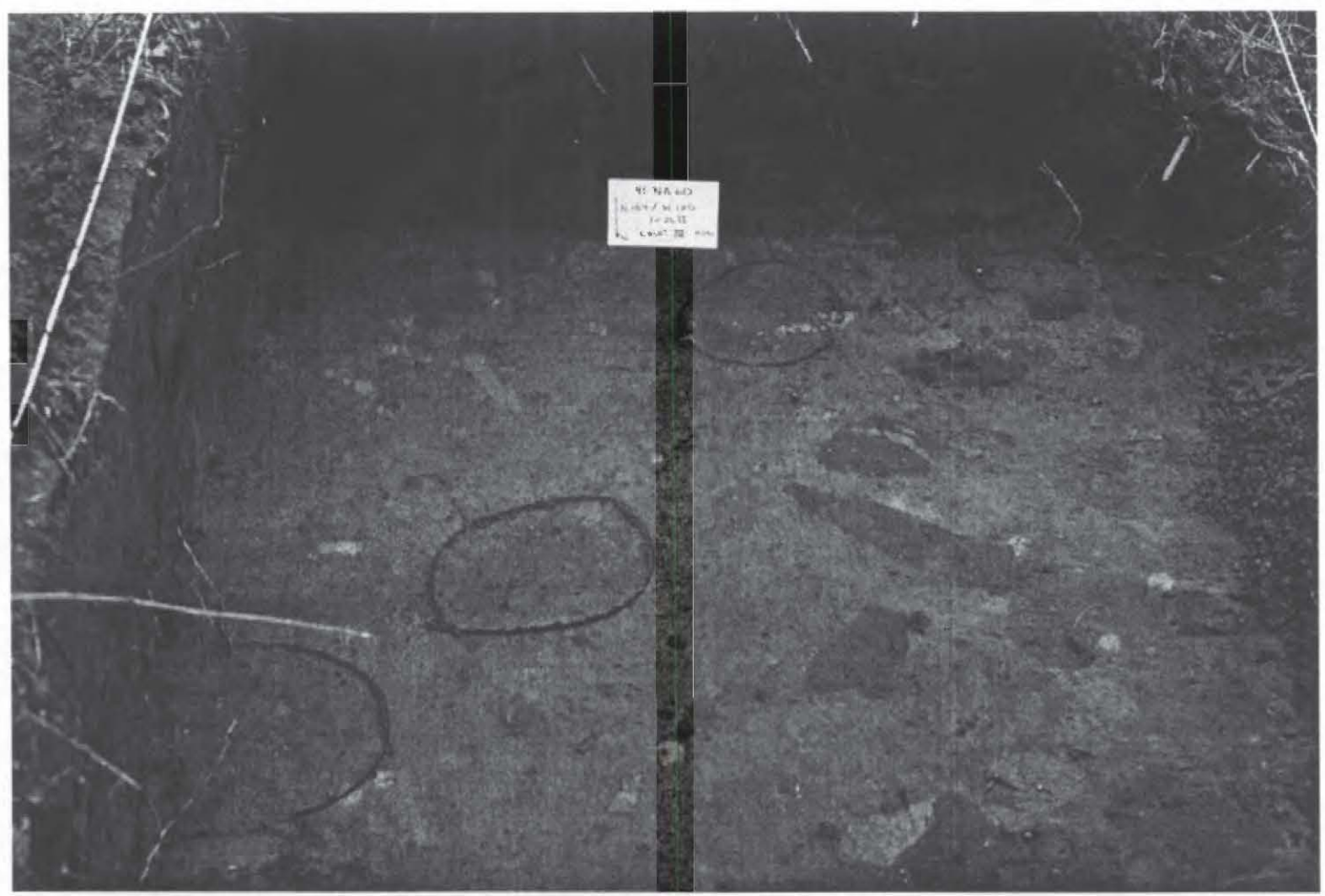

Figure 6. Post hole-sized stains in N154 W120, level 4.

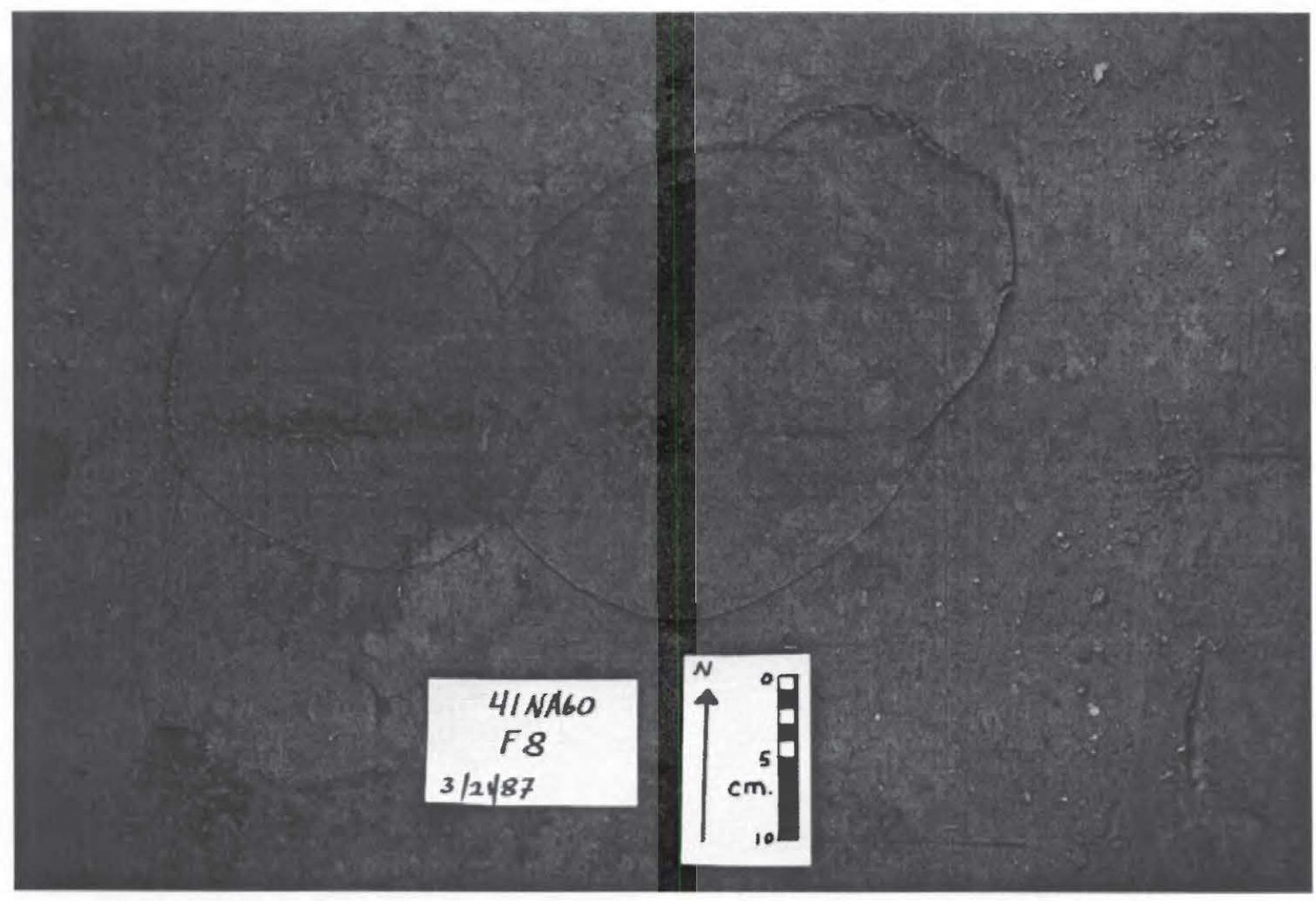

Figure 7. Feature 8 in plan view. 


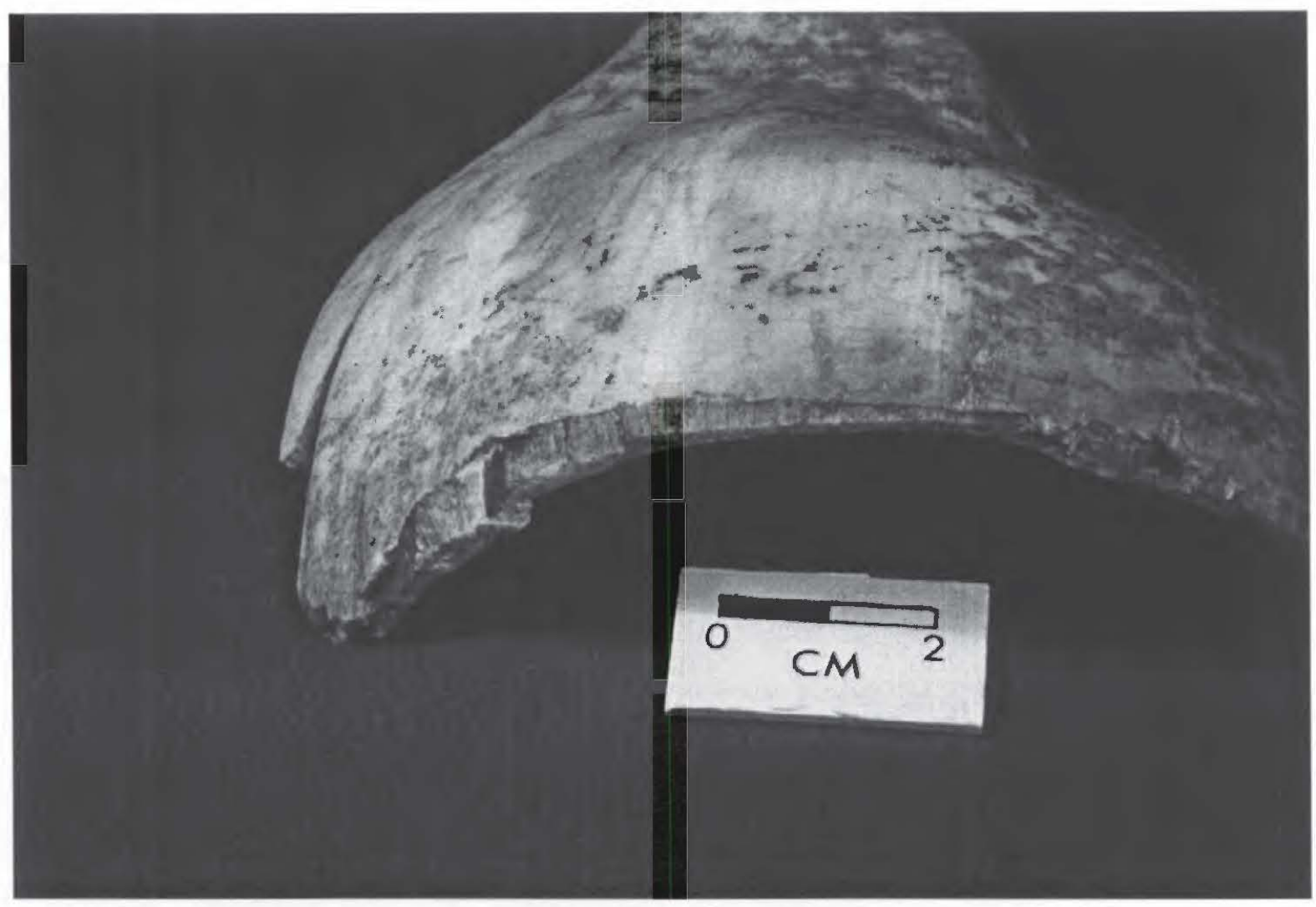

Figure 8. Busycon sp. scoop from Feature 2 at the Henry M. site.

Table 1. Identified fauna from the Henry M. site (41NA60).

\section{Fish}

Bowfish (Amia calva)

Fresh water drum (Aplodinotus grunniens)

Suckerfish (Catostomidae sp.)

Bass/sunfish (Centrarchidae sp.)

Catfish (Ictaluridae sp.)

Gar (Lepisosteus sp.)

\section{Reptiles}

Alligator (Alligator mississippiensis)

Non-poisonous snake (Colubridae sp.)

Red ear turtle (Chrysemys scripta)

Mud/musk turtle (Kinosternidae sp.)

Box turtle (Terrapene sp.)

Softshell turtle (Trionyx sp.)

Large aquatic reptile

\section{Birds}

Hawk (Buteo sp.)

Turkey (Meleagris gallopavo)

\section{Mammals}

Opossum (Didelphis virginianus)

Mountain lion (Felis concolor)

Whitetail deer (Odocoileus virginianus)

Squirrel (Sciurus sp.)

Cottontail rabbit (Sylvilagus floridanus)

Gray fox (Urocyon cinereargenteus)

Large carnivore 
hunting, and animal procurement and trash disposal. It is likely that maize and other plant foods were grown at the site during the occupation. The Patton Engraved sherds and the one Europcan glass bead suggests that the Henry M. site was occupied by a Caddo group in the late $17^{\text {th }}$-early $18^{\text {th }}$ century. Given that Caddo wood structures would probably only last at most 20 ycars before they begin to detcriorate (see Good 1982:69), available featurc evidence suggests that the houses and midden deposit were created over a ca. 20-40 year period by one or two Caddo familics.

Fulure plans for the Henry M. sitc include first completing the analysis of the recovered archaeological materials from the 1985-1991 excavations, including the extensive ceramic and faunal collections. Archaeogeophysical survey work may also be done across the natural sandy rise, and around the block excavations (once the second growth swect gum thicket is removed), to determinc if there are other areas of structures and features at the site beyond those exposed in the cxcavations. Finally, additional excavations may be conducted in the block-or in other locations-to fully expose the Allen phase Caddo structure, including the exterior wall post hole arc and internal structural and domestic household features.

\section{ACKNOWLEDGEMENTS}

Bonnie Yates, then of the University of North Texas, completed an initial inventory and analysis of a sample of the animal bones from the Henry M. site. Sandra Hannum prepared the two maps.

\section{REFERENCES CITED}

Avery, G.

2005 Los Adaes (I6NA I6) Glass Beads. Department of Social Sciences, Northwestern State University of Louisiana, Natchitoches, Louisiana.
Good, C. E.

1982 Analysis of Structures. Burials, and other Cultural Features. In The Deshazo Site, Nacogdoches County, Texas, Volume 1: The Site, Its Setting, Investigations, Cultural Features, A rtifacts of Non-Native Manufacture, and Subsistence Remains, edited by D. A. Story, pp. 51-112 Texas Antiquities Permit Series No. 7. Texas Antiquities Committee, Austin.

Kenmotsu, N. A.

1992 The Mayhew Site: A Possible Hasinai Farmstead. Nacogdoches County, Texas. Bulletin of the Texas Archeological Society 63:135-174.

Kidd, K. E. and M. A. Kidd

1970 A Classification System for Glass Beads for the Use of Field Archaeologists. Occasional Papers in Archaeology and History No. 1:45-89. National Historic Sites Service, National and Historic Parks Branch, Department of Indian Affairs and Northern Development, Ottawa, Ontario.

Middlebrook, T.

2007 A Survey of Historic Caddo Sites in Nacogdoches County. Journal of Northeast Texas Archaeology 26:99-115.

Middlebrook, T. and R. Middlebrook

1996 Or Hearths and Houses. Caddoan Archeology Newsletter 6(4):11-22.

Perttula, T. K., T. E. Emerson, and R. E. Hughes

$200541 \mathrm{Ho}\left(44 / 41 \mathrm{HO} 65\right.$, Late $17^{\text {th }}$ to Early $18^{\text {th }}$ Century Caddo Sites on San Pedro Creek in Houston County, Texas. Bulletin of the Texas Archeological Society 75:85-103.

Story, D. A. (editor)

1982 The Deshazo Site, Nacogdoches County, Texas, Volume 1: The Site, Its Setting, Investigations, Cultural Features, Artifacts of Non-Native Manufacture, and Subsistence Remains. Texas Antiquities Permit Series No. 7. Texas Antiquities Committee, Austin.

1995 The Deshazo Site, Nacogdoches County, Texas, Volume 2: Artifacts of Native Manufacture. Studies in Archeology 21. Texas Archeological Research Laboratory, The University of Texas at Austin. 